\title{
DETERMINAN WANITA UNTUK MELAKUKAN PEMERIKSAAN LANJUTAN SETELAH USG PAYUDARA
}

\section{The Determinant of Women in Conducting Further Examination after Breast Ultrasound}

\author{
Artika Dewi Amri ${ }^{1}$, Ni Luh Putu Suariyani ${ }^{1,2}$ \\ ${ }^{1}$ Program Studi Kesehatan Masyarakat Fakultas Kedokteran Universitas Udayana \\ ${ }^{2}$ Departemen Kesehatan Masyarakat dan Kedokteran Pencegahan, Fakultas Kedokteran Universitas Udayana \\ E-mail: putu_suariyani@unud.ac.id \\ Naskah masuk 31 Agustus 2019; review 30 September 2019; disetujui terbit 26 Juni 2020
}

\begin{abstract}
Background: The further examination after breast ultrasound is needed because the ultrasound examination is not merely recommended for early detection of breast cancer; however by the combination of ultrasound and mammography, the disorder in the breast could be determined more accurately. Mammography method is a method that could detect breast cancer with an accuracy up to 90 percent.

Objective: This study is aimed to identify the determinant of women to conduct further examination after breast ultrasound in Badung.

Method: The study's design used a descriptive observational study with cross-sectional design. The sampling technique used was simple random sampling with a sample of 100 people. The bivariate analysis used chi-square with $\alpha=0.05$.

Result: The results of this study showed that, among the 100 respondents, there were 43 percent have done further examination. The proportion of women taking a further examination was 41 percent with high education, 38 percent with good knowledge, 18 percent stated the distance of health services were far, 43 percent were able to pay the further examination, 38 percent had ever received the information about breast cancer, 43 percent gained the support of health workers and 41 percent received good support from family. The results showed that there were four factors that had a relationship with the further examination after breast ultrasound, including the level of knowledge $(O R=8,65 ; 95 \%$ CI 3,19-23,86), affordability ( $p$-value <0,0001), the support of health workers ( $p$ value <0,0001) and the support of family (OR = 30,3; 95\% CI 6,52-273,73).

Conclusion: The conclusion of this study is that the determinant of women to undertake the further examination after breast ultrasound depends on the level of knowledge, affordability, the support of health workers and the support of family. There is a need of an increase in socialization about breast cancer to women and husband/family. In addition, to increase further examination there is a need of socialization regarding the utilization of BPJS.
\end{abstract}

Keywords: breast cancer, advanced examination, breast ultrasound

Abstrak
Latar belakang: Pemeriksaan lanjutan setelah USG payudara perlu dilakukan karena pemeriksaan USG saja tidak direkomendasikan untuk deteksi dini kanker payudara, tetapi dengan kombinasi USG dan mammografi kelainan pada payudara dapat ditentukan lebih akurat. Metode mammografi merupakan metode yang dapat mendeteksi kanker payudara dengan akurasi sampai 90 persen.

Tujuan: Penelitian ini bertujuan untuk mengetahui determinan wanita untuk melakukan pemeriksaan lanjutan setelah USG payudara di Kabupaten Badung.

Metode: Desain penelitian menggunakan studi observasional deskriptif dengan desain potong lintang. Teknik pengambilan sampel yang digunakan simple random sampling dengan jumlah sampel 100 orang. Analisis bivariat menggunakan chi-square dengan $\alpha=0,05$.

Hasil: Hasil penelitian ini menggambarkan dari 100 responden sebanyak 43 persen sudah melakukan pemeriksaan lanjutan. Proporsi wanita yang melakukan pemeriksaan lanjutan sebanyak 41 persen orang berpendidikan tinggi, 38 persen orang berpengetahuan baik, 18 persen orang menyatakan jarak pelayanan kesehatan jauh, 43 persen orang mampu untuk membiayai pemeriksaan lanjutan, 38 persen pernah memperoleh informasi tentang kanker payudara, 43 persen orang memperoleh dukungan petugas kesehatan, dan 41 persen memperoleh dukungan baik dari keluarga. Hasil penelitian menunjukkan terdapat empat faktor yang memiliki hubungan terhadap pemeriksaan lanjutan setelah USG payudara yaitu tingkat pengetahuan ( $\mathrm{OR}=8,65 ; 95 \%$ CI 3,19-23,86), keterjangkauan biaya (p-value <0,0001), dukungan petugas kesehatan (p-value <0,0001) dan dukungan keluarga $(\mathrm{OR}=30,3 ; 95 \% \mathrm{CI}$ 6,52-273,73).

Kesimpulan: Simpulan penelitian adalah determinan wanita untuk melakukan pemeriksaan lanjutan setelah USG payudara adalah tingkat pengetahuan, keterjangkauan biaya, dukungan petugas kesehatan, dan dukungan keluarga. Perlu adanya peningkatan sosialiasasi mengenai kanker payudara kepada wanita dan suami/keluarga. Selain itu untuk meningkatkan pemeriksaan lanjutan perlu adanya sosialisasi mengenai pemanfaatan BPJS Kesehatan.

Kata kunci: kanker payudara, pemeriksaan lanjutan, USG Payudara 


\section{PENDAHULUAN}

Kanker merupakan salah satu penyakit yang ditakuti dan dipandang sebagai penyebab utama kematian di seluruh dunia. ${ }^{1}$ Berdasarkan data dari WHO (2011), kanker merupakan penyebab kematian terbanyak di dunia dimana kanker penyumbang kematian nomor dua yaitu sebesar 3 persen setelah penyakit kardiovaskuler. ${ }^{2}$ Salah satu kanker yang paling banyak diderita adalah kanker payudara yaitu 8-9 persen wanita mengalaminya. ${ }^{2,3}$ Menurut data GLOBOCAN (IARC) tahun 2015 terdapat 231.840 kasus baru kanker payudara dan diestimasi sebanyak 40.290 wanita meninggal dunia. Pada tahun 2016 diestimasi jumlah kasus baru meninggal menjadi 246.660 kasus dan sebanyak 40.450 wanita yang meninggal akibat kanker payudara. ${ }^{4}$

Berdasarkan Pusat Data dan Informasi Kementerian Kesehatan RI tahun 2015, prevalensi penyakit kanker payudara di Indonesia pada tahun 2013 yaitu sebesar 0,05 persen. ${ }^{5}$ Pusat Data dan Informasi Kementerian Kesehatan RI menyatakan bahwa di Provinsi Bali prevalensi dan estimasi jumlah penderita kanker payudara pada tahun 2013 sekitar 1.233 orang penderita kanker payudara. ${ }^{3}$ Laporan tahunan Dinas Kesehatan Provinsi Bali tahun 2011 menyatakan bahwa persentase penderita kanker payudara dengan diagnosis awal stadium lanjut mencapai 75 persen dan stadium awal 25 persen. $^{6}$

Masalah kanker payudara menjadi lebih besar karena lebih dari 70 persen penderita datang ke pelayanan kesehatan pada stadium lanjut. ${ }^{3}$ Hasil penelitian Taha (2010) di Rumah Sakit Umum Haji Adam Malik Medan menunjukkan tingginya persentase penderita kanker payudara stadium lanjut datang ke pelayanan kesehatan pertama kali untuk memeriksakan diri yaitu pada stadium IV sebesar 39,7 persen dan stadium IIIB sebesar 34,5 persen. ${ }^{6,7}$ Penderita kanker payudara yang terdeteksi pada stadium lanjut tidak bisa diterapi dengan operasi saja melainkan harus dipadukan dengan kemoterapi. Angka kelangsungan hidup rendah ditemukan

*Korespondensi: putu_suariyani@unud.ac.id

(C) Badan Penelitian dan Pengembangan Kesehatan ISSN: 2354-8762 (elektronik); ISSN: 2087-703X (cetak) pada stadium lanjut yaitu sebesar 15 persen pada stadium IV dan 30 - 50 persen pada stadium III. ${ }^{8}$ Oleh karena itu, upaya deteksi dini kanker payudara sangat penting dilakukan karena jika kanker payudara dapat dideteksi sedini mungkin, maka tindakan secara tepat dapat dilakukan sehingga didapatkan tingkat kesembuhan yang cukup tinggi yaitu sekitar 8090 persen serta dapat menurunkan angka kematian akibat kanker. ${ }^{9,10}$

Data di Kabupaten Badung tahun 2013 menunjukkan prevalensi kanker pada semua umur berdasarkan diagnosis mencapai 0,51 persen. Kabupaten Badung merupakan salah satu Kabupaten di Provinsi Bali yang saat ini gencar melakukan deteksi dini kanker payudara dengan sasaran wanita yang berada di wilayah Kabupaten Badung. Program yang dijalankan merupakan program deteksi dini bergerak (mobile) berupa mobil bus dengan desain khusus yang dilengkapi alat USG ABVS (Automated Breast Volume Scanner). Alat ABVS yang digunakan dalam melakukan deteksi dini akan menghasilkan gambaran pada payudara yang disebut sebagai BIRADS (Breast Imaging Reporting and Data System) yang dikategorikan menjadi 6 kategori. Berdasarkan hasil pemeriksaan tersebut perlu dilakukan pemeriksaan lanjutan untuk mengetahui secara pasti kelainan pada payudara. Perlunya pemeriksaan lanjutan karena pemeriksaan USG saja tidak direkomendasikan untuk deteksi kanker payudara, tetapi dengan kombinasi USG dan mammografi kelainan pada payudara dapat ditentukan lebih akurat. ${ }^{11}$ Metode mammografi merupakan metode yang dapat mendeteksi kanker payudara dengan akurasi sampai 90 persen. Selaras dengan hal ini, penelitian yang dilakukan Huang, et al (2012) menunjukkan bahwa pemeriksaan deteksi dini kanker payudara yang dilakukan dengan USG terlebih dahulu, lalu jika diindikasi maka dilanjutkan dengan pemeriksaan mammografi yang memiliki tingkat spesitivitas tinggi $(99,4 \%)$ dan sensitivitas $(84,8 \%)$ yang akan mengoptimalkan pemeriksaan deteksi dini kanker payudara. ${ }^{12}$ 
Pada pemeriksaan USG tidak diketahui apakah wanita yang telah melakukan deteksi dini kanker payudara dan didiagnosa ada kelainan pada payudara melakukan pemeriksaan lebih lanjut ke pelayanan kesehatan atau tidak untuk melakukan pemeriksaan lebih lanjut. Hal ini penting untuk diketahui karena jika wanita yang telah didiagnosa dengan hasil USG mengalami kelainan pada payudara namun tidak melakukan pemeriksaan lanjutan maka wanita tersebut tidak mengetahui secara pasti adanya kelainan pada dirinya dan tidak mendapatkan tindakan secara tepat dan cepat. Dalam melakukan pemeriksaan lanjutan deteksi dini kanker payudara banyak faktor yang akan mempengaruhi kesediaan wanita untuk memeriksakan dirinya ke pelayanan kesehatan. Hal ini berhubungan dengan perilaku kesehatan wanita tersebut, dimana perilaku kesehatan menurut Lawrence Grenn dipengaruhi oleh faktor predisposisi, pendukung dan pendorong dalam melakukan pemeriksaan lanjutan. ${ }^{13}$ Menurut The American Cancer Society merekomendasikan agar mammogram dilakukan setiap tahun saat seorang wanita memasuki usia 40 tahun. ${ }^{14}$

Pada penelitian yang dilakukan Desanti, dkk (2010) mengenai persepsi wanita berisiko kanker payudara tentang pemeriksaan payudara sendiri di kota Semarang, Jawa Tengah menyatakan bahwa 74,8 persen responden merasa perilaku SADARI tidak mempunyai keuntungan dan 70,1 persen responden merasakan hambatan untuk melakukan SADARI. ${ }^{11}$ Hasil penelitian tersebut bertolak belakang dengan kenyataan bahwa responden adalah wanita yang mempunyai faktor risiko kanker payudara yang seharusnya akan merasa rentan untuk terkena kanker payudara. Selain itu penelitian mengenai faktor-faktor keterlambatan penderita kanker payudara dalam melakukan pemeriksaan awal ke pelayanan kesehatan menyatakan bahwa hasil analisis menunjukkan semakin rutin melakukan SADARI maka dapat terhindar dari keterlambatan dalam melakukan pemeriksaan awal kanker payudara ke pelayanan kesehatan. Orang yang tidak pernah melakukan SADARI mempunyai risiko 11,08 kali dan orang yang tidak rutin melakukan SADARI mempunyai risiko 5,18 kali untuk mengalami keterlambatan melakukan pemeriksaan awal kanker payudara ke pelayanan kesehatan dibandingkan orang yang rutin melakukan deteksi dini SADARI setiap bulan. ${ }^{15}$

Tujuan dari penulisan ini untuk mengetahui determinan wanita dalam melakukan pemeriksaan lanjutan setelah USG Payudara. Hasil penelitian ini diharapkan dapat digunakan untuk memberikan masukan dan informasi sebagai salah satu pertimbangan untuk keberlanjutan program deteksi kanker payudara yang bertujuan untuk penemuan penderita kanker payudara sedini mungkin serta tindakan yang tepat dan cepat.

\section{METODE}

Penelitian ini merupakan penelitian observasional deskriptif dengan desain potong lintang. Sampel penelitian adalah wanita yang berumur $\geq 40$ tahun dan telah melakukan pemeriksaan payudara dengan metode USG melalui Program Deteksi Dini Kanker Payudara Kabupaten Badung dengan hasil BIRADS 2 (kelainan jinak), 3 (kelainan yang mungkin jinak dan disarankan untuk evaluasi), 4 (kelainan yang mungkin mengarah keganasan), 5 (sangat mungkin ganas), dan 6 (ganas). Teknik pemilihan sampel yang digunakan dalam penelitian ini adalah probability random sampling yaitu simple random sampling. Jumlah sampel sebanyak 100 orang, besar sampel dihitung dengan confidence level 95 persen, presisi 8 persen, proporsi perilaku deteksi dini sebesar 55 persen dan populasi wanita umur $\geq 40$ tahun dengan hasil BIRADS 2, 3, 4, 5, dan 6 sebesar 248 orang.

Variabel tergantung dalam penelitian ini adalah kesediaan pemeriksaan lanjutan setelah USG payudara. Variabel bebas meliputi tingkat pendidikan, tingkat pengetahuan, keterjangkauan jarak, keterjangkauan biaya, sumber informasi, dukungan petugas kesehatan, dan dukungan keluarga. Jenis data yang diperlukan adalah data primer yaitu diperoleh dari hasil wawancara dengan menggunakan kuesioner terstruktur dan data sekunder yaitu data yang diperoleh dari daftar registrasi wanita yang telah melakukan pemeriksaan di Program Deteksi Dini Kanker Payudara Kabupaten Badung. 
Analisis data berupa analisis univariat yang bertujuan untuk mendapatkan gambaran distribusi frekuensi masing-masing variabel dan analisis bivariat untuk mengetahui hubungan dari setiap variabel bebas dengan variabel tergantung menggunakan uji chisquare derajat kepercayaan $95 \%$.

\section{HASIL}

Berdasarkan Tabel 1 karakteristik responden, kelompok umur terbanyak terdapat pada kelompok umur 40 - 49 tahun mencapai 76 orang $(76 \%)$. Karakteristik berdasarkan pendidikan responden, sebagian besar tamat SMA sebanyak 47 orang (47\%) dan Diploma/Sarjana sebanyak 44 orang (44\%). Sebagian besar responden bekerja sebagai PNS yaitu sebanyak 45 orang (45\%) dan sebanyak 29 orang (29\%) adalah ibu rumah tangga.

Tabel 1. Karakteristik Responden

\begin{tabular}{lcc}
\hline Karakteristik & $\begin{array}{c}\text { Frekuensi } \\
(\mathbf{N = 1 0 0})\end{array}$ & Persentase \\
\hline Umur & & \\
& & \\
$40-49$ tahun & 22 & $76 \%$ \\
$50-59$ tahun & 2 & $22 \%$ \\
$60-69$ tahun & & $2 \%$ \\
\hline Pekerjaan & 45 & \\
PNS & 17 & $45 \%$ \\
Wiraswasta & 8 & $17 \%$ \\
Pegawai swasta & 1 & $8 \%$ \\
Buruh & 29 & $1 \%$ \\
IRT & & \\
Riwayat keluarga kanker & 9 & $9 \%$ \\
Ya & 91 & $91 \%$ \\
Tidak & & \\
Hasil USG & & $94 \%$ \\
BIRADS 2 & 94 & $2 \%$ \\
BIRADS 3 & 2 & $2 \%$ \\
BIRADS 4 & 2 & $2 \%$ \\
BIRADS 5 & 2 & $0 \%$ \\
BIRADS 6 & 0 & \\
\hline
\end{tabular}

Karakteristik berdasarkan ada/tidaknya riwayat kanker pada keluarga, sebagian besar responden tidak memiliki riwayat kanker pada keluarga yaitu sebanyak 91 orang $(91 \%)$ dan responden yang memiliki riwayat kanker pada keluarga sebanyak 9 orang (9\%). Sebagian besar responden pada saat melakukan USG Payudara memperoleh hasil BIRADS 2 sebanyak 94 orang (94\%) dan BIRADS 3, 4, dan 5 masing-masing sebanyak 2 orang (2\%).
Tidak ada responden yang memperoleh hasil USG Payudara dengan BIRADS 6.

Berdasarkan tabel 2, diperoleh responden yang telah melakukan pemeriksaan lanjutan setelah USG Payudara sebanyak 43 orang (43\%) sedangkan responden yang tidak melakukan pemeriksaan lanjutan setelah USG Payudara sebanyak 57 orang $(57 \%)$. 
Tabel 2. Distribusi Frekuensi Pemeriksaan Lanjutan Setelah USG Payudara

\begin{tabular}{ccc}
\hline Variabel & $\begin{array}{c}\text { Frekuensi } \\
(\mathbf{N = 1 0 0 )}\end{array}$ & Persentase \\
\hline Pemeriksaan lanjutan & & \\
Tidak & 57 & $57 \%$ \\
Sudah & 43 & $43 \%$ \\
\hline
\end{tabular}

Berdasarkan Tabel 3, hasil analisis hubungan tingkat pendidikan dengan pemeriksaan lanjutan setelah USG payudara diperoleh nilai Odds Ratio $(\mathrm{OR})=2,87$, menunjukkan bahwa orang yang berpendidikan tinggi meningkatkan peluang untuk melakukan pemeriksaan lanjutan setelah USG payudara sebesar 2,87 kali dibandingkan dengan orang yang berpendidikan rendah. Nilai $95 \%$ CI $0,50-$ 29,49 menunjukkan bahwa peluang responden yang berpengetahuan tinggi untuk melakukan pemeriksaan lanjutan setelah USG yaitu 0,50 kali sampai 29,49 kali, namun 95\% CI melewati angka 1 menunjukkan tidak ada pengaruh antara tingkat pendidikan dengan pemeriksaan lanjutan setelah USG payudara.

Tabel 3. Hubungan Determinan Wanita Untuk Melakukan Pemeriksaan Lanjutan Setelah USG Payudara

\begin{tabular}{|c|c|c|c|c|c|}
\hline \multirow[t]{2}{*}{ Variabel } & \multicolumn{2}{|c|}{$\begin{array}{c}\text { Pemeriksaan lanjutan } \\
\text { f }(\%)\end{array}$} & \multirow[t]{2}{*}{ OR } & \multirow[t]{2}{*}{$\mathbf{P}$} & \multirow[t]{2}{*}{$95 \% \mathrm{CI}$} \\
\hline & Tidak & Ya & & & \\
\hline \multicolumn{6}{|l|}{ Faktor predisposisi } \\
\hline Tingkat pendidikan & & & 2,48 & 0,18 & $0,50-29,49$ \\
\hline Rendah & $7(77,78)$ & $2(22,22)$ & & & \\
\hline Tinggi & $50(54,59)$ & $41(45,05)$ & & & \\
\hline Tingkat pengetahuan & & & 8,65 & $<0,0001$ & $3,19-23,86$ \\
\hline Kurang & $45(77,59)$ & $13(22,41)$ & & & \\
\hline Baik & $12(28,57)$ & $30(71,43)$ & & & \\
\hline \multicolumn{6}{|l|}{ Faktor pendukung } \\
\hline Keterjangkauan jarak & & & 1,33 & 0,48 & $0,54-3,25$ \\
\hline Jauh & $37(59,68)$ & $25(40,32)$ & & & \\
\hline Dekat & $20(52,63)$ & $18(47,37)$ & & & \\
\hline Keterjangkauan biaya* & & & - & $<0,0001$ & - \\
\hline Tidak mampu & $18(100)$ & $0(0,00)$ & & & \\
\hline Mampu & $39(47,56)$ & $43(52,44)$ & & & \\
\hline \multicolumn{6}{|l|}{ Faktor pendorong } \\
\hline Sumber informasi & & & 2,47 & 0,10 & $0,74-9,53$ \\
\hline Tidak & $14(73,68)$ & $5(26,32)$ & & & \\
\hline $\mathrm{Ya}$ & $43(53,09)$ & $38(46,91)$ & & & \\
\hline Dukungan keluarga & & & 30,30 & $<0,0001$ & $6,52-273,73$ \\
\hline Tidak & $34(94,44)$ & $2(5,56)$ & & & \\
\hline $\mathrm{Ya}$ & $23(35,94)$ & $41(64,06)$ & & & \\
\hline $\begin{array}{l}\text { Dukungan petugas } \\
\text { kesehatan* }\end{array}$ & & & - & $<0,0001$ & - \\
\hline Tidak & $25(100)$ & $0(0,00)$ & & & \\
\hline $\mathrm{Ya}$ & $32(42,67)$ & $43(57,33)$ & & & \\
\hline
\end{tabular}

Keterangan $:{ }^{*}$ Fisher exact 
Hasil analisis hubungan tingkat pengetahuan dengan pemeriksaan lanjutan setelah USG payudara diperoleh bahwa nilai Odds Ratio $(\mathrm{OR})=11,23 \quad(95 \%$ CI $3,56-41,03)$, menunjukkan orang dengan tingkat pengetahuan baik meningkatkan peluang untuk melakukan pemeriksaan lanjutan setelah USG payudara sebesat 11,23 kali dibandingkan dengan orang yang berpengetahuan kurang.

Berdasarkan hasil analisis hubungan keterjangkauan jarak pelayanan kesehatan dengan pemeriksaan lanjutan setelah USG payudara diperoleh nilai Odds Ratio $(\mathrm{OR})=$ 1,33 dan nilai $95 \%$ CI 0,54 - 3,25, menunjukkan bahwa keterjangkauan jarak tidak berpengaruh dengan pemeriksaan lanjutan setelah USG payudara.

Hasil analisis hubungan keterjangkauan biaya dengan pemeriksaan lanjutan setelah USG payudara diperoleh bahwa responden dengan ketidakmampuan menjangkau pelayanan kesehatan dari segi biaya sebanyak 18 orang (100\%) tidak melakukan pemeriksaan lanjutan, sedangkan responden yang mampu sebanyak 39 orang $(47,56 \%)$ tidak melakukan pemeriksaan lanjutan dan sebanyak 43 orang $(52,44 \%)$ melakukan pemeriksaan lanjutan. Hasil penelitian ini menunjukkan nilai p-value $<0,0001$ artinya keterjangkauan biaya berpengaruh terhadap pemeriksaan lanjutan setelah USG payudara. Responden yang tidak mampu tidak ada yang melakukan pemeriksaan lanjutan setelah USG payudara.

Berdasarkan hasil analisis hubungan sumber informasi tentang kanker payudara dengan pemeriksaan lanjutan setelah USG payudara diperoleh nilai Odds Ratio $(\mathrm{OR})=2,43$, menunjukkan orang yang pernah terpapar sumber informasi tentang kanker payudara meningkatkan peluang untuk melakukan pemeriksaan lanjutan setelah USG payudara sebesar 2,43 kali dibandingkan dengan orang yang tidak pernah terpapar sumber informasi tentang kanker payudara. Nilai 95\% CI 0,74 9,53 menunjukkan bahwa peluang responden yang pernah memperoleh informasi tentang kanker payudara untuk melakukan pemeriksaan lanjutan setelah USG payudara yaitu 0,74 kali sampai 9,53 kali, namun 95\% CI melewati angka 1 menunjukkan tidak ada pengaruh antara sumber informasi dengan pemeriksaan lanjutan setelah USG payudara.
Hasil analisis hubungan dukungan petugas kesehatan dengan pemeriksaan lanjutan setelah USG payudara diperoleh bahwa, responden yang tidak memperoleh dukungan petugas kesehatan sebanyak 25 orang (100\%) tidak melakukan pemeriksaan lanjutan, sedangkan responden yang memperoleh dukungan petugas kesehatan sebanyak 32 orang $(42,67 \%)$ tidak melakukan pemeriksaan lanjutan. Hasil penelitian ini menunjukkan nilai p-value $<0,0001$ artinya dukungan petugas kesehatan berpengaruh terhadap pemeriksaan lanjutan setelah USG payudara. Responden yang tidak memperoleh dukungan dari petugas kesehatan tidak ada yang melakukan pemeriksaan lanjutan setelah USG payudara.

Berdasarkan hasil analisis hubungan dukungan keluarga dengan pemeriksaan lanjutan setelah USG payudara diperoleh nilai Odds Ratio (OR) $=12,88(95 \%$ CI 2,78 - 118,14), menunjukkan bahwa orang dengan dukungan keluarga baik meningkatkan peluang untuk melakukan pemeriksaan lanjutan setelah USG sebesar 12,88 kali dibandingkan orang yang memiliki dukungan keluarga kurang.

\section{PEMBAHASAN}

Pemeriksaan lanjutan setelah USG payudara ini dapat dilatarbelakangi oleh berbagai faktor antara lain pendidikan, pengetahuan, keterjangkauan jarak, keterjangkauan biaya, sumber informasi, dukungan keluarga, dan dukungan petugas kesehatan. Pendidikan adalah upaya yang direncanakan untuk mempengaruhi orang lain baik individu, kelompok atau masyarakat sehingga mereka melakukan apa yang diharapkan oleh pelaku pendidikan. Tingkat pendidikan yang ditempuh oleh individu merupakan salah satu faktor yang akan mendukung kemampuannya untuk menerima informasi. Semakin tinggi tingkat pendidikan seseorang maka semakin luas pula cara pandang dan pikirnya dalam menghadapi suatu keadaan yang terjadi disekitarnya. ${ }^{13}$ Status pendidikan akan berpengaruh terhadap pengetahuan dan sikap responden. Status pendidikan yang baik akan membuat responden termotivasi untuk memelihara kesehatan dengan lebih baik. Hasil penelitian ini menunjukkan bahwa orang dengan tingkat pendidikan tinggi meningkatkan peluang untuk melakukan pemeriksaan lanjutan setelah USG 
payudara sebesar 2,48 kali dibandingkan orang dengan tingkat pendidikan rendah. Namun, dilihat dari $95 \%$ CI 0,50 - 29,4 menunjukkan tidak berpengaruh variabel tingkat pendidikan terhadap pemeriksaan lanjutan setelah USG payudara. Menurut Lawrence Green (1980) menyatakan bahwa pendidikan menjadi salah satu faktor dalam diri seseorang yang dapat mempengaruhi perilaku atau tindakan seseorang dalam upaya kesehatan. Seseorang dengan tingkat pendidikan tinggi cenderung mempunyai pola pikir yang lebih berkembang dan lebih logis. Pendidikan memiliki efek positif terhadap kesadaran kesehatan dan secara langsung berimbas pada perilaku kesehatan. Perbedaan hasil penelitian ini kemungkinan disebabkan proporsi tingkat pendidikan rendah lebih kecil dibandingkan dengan proporsi tingkat pendidikan tinggi, sehingga pendidikan tidak berpengaruh terhadap pemeriksaan lanjutan setelah USG payudara.

Penelitian Dyanti \& Suariyani (2016) yang menyatakan bahwa orang dengan tingkat pendidikan rendah (tidak sekolah/SD/SMP) mempunyai risiko 5,67 kali untuk mengalami keterlambatan dalam melakukan pemeriksaan awal kanker payudara ke pelayanan kesehatan dibandingkan dengan orang yang memiliki tingkat pendidikan tinggi (diploma/sarjana). ${ }^{15}$ Penelitian yang dilakukan oleh Pradono dan Sulistyowati (2013) menyatakan bahwa hasil analisis menunjukkan adanya hubungan yang positif dan signifikan antara tingkat pendidikan dengan status kesehatan. ${ }^{16}$ Selain itu, penelitian lain menyatakan bahwa dari 44 orang responden yang sudah pernah melakukan IVA sebanyak 28 orang $(31,8 \%)$ merupakan lulusan SMA, sebanyak 10 orang $(11,4 \%)$ merupakan lulusan perguruan tinggi dan sebanyak 3 orang $(3,4 \%)$ merupakan lulusan SD. ${ }^{17}$

Pengetahuan merupakan salah satu faktor yang melatarbelakangi seseorang untuk berperilaku. Pengetahuan adalah hasil penginderaan manusia atau hasil tahu seseorang terhadap objek melalui indra yang dimilikinya. Pengetahuan seseorang terhadap objek mempunyai intensitas atau tingkat yang berbeda-beda. ${ }^{13}$ Berdasarkan teori Lawrence Green (1980) yang menyatakan bahwa pengetahuan merupakan salah satu dari faktor predisposisi, yaitu faktor yang bersumber dari dalam diri seseorang yang mempengaruhi tindakan dan perilaku terhadap kesehatan. ${ }^{18} \mathrm{Hal}$ ini menunjukkan semakin tinggi tingkat pengetahuan, kesadaran dalam melakukan deteksi dini maupun dalam pemeriksaan lanjutan akan semakin tinggi. Pengetahuan tentang suatu objek mengandung dua aspek yaitu aspek positif dan aspek negatif. Kedua aspek ini yang akan menentukan sikap seseorang, semakin banyak aspek positif dan objek yang diketahui maka akan menimbulkan sikap semakin positif terhadap objek tertentu.

Penelitian ini menunjukkan bahwa peluang orang yang berpengetahuan tinggi untuk melakukan pemeriksaan lanjutan setelah USG payudara yaitu 3,57 kali sampai 41,03 kali. Beberapa penelitian yang mendukung antara lain penelitian yang dilakukan oleh Hastuti (2010) menyatakan bahwa adanya hubungan antara tingkat pengetahuan tentang kanker payudara dengan perilaku deteksi dini kanker payudara pada wanita usia subur. ${ }^{19}$ Penelitian lain yang dilakukan oleh Mirayashi, dkk (2010) menyatakan bahwa dari 44 orang yang telah mengikuti pemeriksaan IVA, sebanyak 17 persen memiliki tingkat pengetahuan yang baik, sebanyak 28,4 persen memiliki tingkat pengetahuan sedang dan sebanyak 4,5 persen memiliki tingkat pengetahuan kurang. ${ }^{17}$ Penelitian Yuliwati (2012) menunjukkan hubungan antara pengetahuan dengan perilaku periksa IVA. Proporsi WUS dengan IVA baik sebanyak 66,1 persen berpengetahuan baik dan 32,7 persen berpengetahuan kurang. ${ }^{20}$

Jarak fasilitas kesehatan yang berdekatan dengan tempat tinggal masyarakat, memberikan peluang kepada masyarakat untuk melakukan pemeriksaan kesehatan lebih awal terhadap gejala sakit yang dirasakan. Pada penelitian ini, keterjangkauan jarak fasilitas kesehatan tidak berpengaruh dengan pemeriksaan lanjutan setelah USG payudara. Sedangkan penelitian yang dilakukan oleh Dyanti \& Suariyani (2016) menyatakan bahwa faktor jarak bukan merupakan faktor risiko keterlambatan penderita kanker payudara dalam melakukan pemeriksaan awal ke pelayanan kesehatan. ${ }^{15}$ Hasil penelitian Erlina, dkk (2014) di daerah perkotaan dengan sarana transportasi yang memadai sehingga mempermudah akses ibu hamil ke pelayanan kesehatan, sebanyak 74,6 persen responden menyatakan dapat menjangkau pelayanan kesehatan untuk melakukan pemeriksaan kehamilan. $^{21}$ Selain itu, penelitian Nurtini 
(2012) menyatakan jarak yang dekat antara rumah responden dengan fasilitas kesehatan memiliki cakupan IVA yang tinggi yaitu 35,2 persen dibandingkan jarak yang jauh dengan cakupan IVA 3,8 persen. ${ }^{22}$

Perbedaan hasil penelitian yang menyatakan bahwa keterjangkauan jarak fasilitas kesehatan dengan pemeriksaan lanjutan setelah USG payudara tidak berpengaruh karena responden bertempat tinggal di Kabupaten Badung yang tersebar di enam kecamatan antara lain Kecamatan Petang, Abiansemal, Mengwi, Kuta Utara, Kuta, dan Kuta Selatan, sedangkan fasilitas tingkat rujukan milik pemerintah yaitu RSUD Badung terletak di Kecamatan Mengwi. Jarak masing-masing kecamatan tersebut cukup jauh menuju fasilitas tingkat rujukan, akan tetapi mudah dilalui dengan transportasi baik roda dua maupun roda empat. Sehingga diperoleh persepsi responden bahwa jarak rumah menuju fasilitas kesehatan rujukan cukup jauh namun mudah dijangkau.

Tingkat ekonomi merupakan salah satu faktor pendukung seseorang untuk melakukan pemeriksaan kesehatan. Hal ini didukung oleh Notoatmodjo (2014) yang menyatakan bahwa ekonomi adalah salah satu faktor yang sangat mempengaruhi perilaku masyarakat, apabila penghasilan masyarakat cukup maka mereka akan memenuhi kebutuhan dengan maksimal dan sebaliknya apabila penghasilan masyarakat kurang maka mereka akan mengabaikan kebutuhannya termasuk dalam mencari pelayanan kesehatan. ${ }^{13}$ Hasil penelitian ini membuktikan bahwa pembiayaan dalam mengakses pelayanan kesehatan yang cukup mahal merupakan salah satu kendala responden untuk melakukan pemeriksaan lanjutan.

Penelitian Dyanti \& Suariyani (2016) menunjukkan bahwa faktor pemungkin atau pendukung dipengaruhi salah satunya oleh aksesibilitas ekonomi yaitu dilihat dari kemampuan finansial responden untuk mengakses pelayanan kesehatan, orang yang tidak mampu dari segi ekonomi dalam mengakses pelayanan kesehatan mempunyai risiko 5,95 kali untuk mengalami keterlambatan dalam melakukan pemeriksaan awal kanker payudara ke pelayanan kesehatan dibandingkan orang yang mampu dalam mengakses pelayanan kesehatan. $^{15}$ Penelitian yang dilakukan oleh Martini (2013) menunjukkan bahwa proporsi tertinggi responden melakukan pemeriksaan pap smear pada kelompok responden dengan penghasilan tinggi sebanyak 64,5 persen, sedangkan proporsi terendah responden melakukan tindakan pemeriksaan pap smear adalah responden dengan penghasilan rendah 31,6 persen. ${ }^{23}$

Sumber informasi kesehatan yang efektif sangat penting kaitannya dalam meningkatkan pengetahuan dan sikap positif untuk mencegah terjadinya penyebaran penyakit serta membantu dalam pengambilan keputusan. Informasi dapat berasal dari mana saja baik dari petugas kesehatan, keluarga, teman maupun melalui media massa dan media cetak. Pada penelitian ini, sumber informasi yang dimaksud adalah sumber informasi yang diperoleh responden tentang kanker payudara sebelum melakukan pemeriksaan USG payudara. Pada penelitian ini menunjukkan bahwa sumber informasi tidak berpengaruh dengan pemeriksaan lanjutan setelah USG payudara. Hasil penelitian yang dilakukan oleh Rohmawati (2010) menyimpulkan bahwa keterpaparan seseorang terhadap informasi kesehatan akan mendorong terjadinya perilaku kesehatan. ${ }^{24}$ Penelitian lain yang dilakukan oleh Yuliwati (2012) menyatakan bahwa terdapat hubungan yang signifikan antara keterpaparan informasi dengan perilaku WUS dalam melakukan periksa IVA test. ${ }^{20}$

Pada hasil penelitian menunjukkan bahwa responden dalam memutuskan untuk melakukan pemeriksaan lanjutan tidak dipengaruhi oleh keterpaparan sumber informasi tentang kanker payudara yang pernah diperoleh sebelum melakukan USG payudara. Selain itu, pemeriksaan USG payudara yang dilaksanakan merupakan program pemerintah daerah Kabupaten Badung yang tidak dipungut biaya dan pelayanan yang dilakukan adalah pelayanan jemput bola sehingga responden yang memeriksakan dirinya tersebut kemungkinan bukan disebabkan dari informasi tentang kanker payudara yang pernah diperoleh sebelumnya namun disebabkan karena adanya pelayanan kesehatan yang datang ke tempat tinggal responden.

Dukungan yang diberikan oleh petugas kesehatan dapat membangkitkan rasa percaya diri untuk membuat keputusan. Dukungan yang diberikan antara lain berupa informasi mengenai kesehatan yang dapat meningkatkan pengetahuan. Pengetahuan yang diperoleh 
tersebut dapat menimbulkan motivasi dari seseorang untuk melakukan sesuatu sesuai dengan pengetahuan yang dimilikinya. Sikap dari petugas kesehatan juga akan memberikan motivasi bagi responden. Sikap positif dapat ditunjukkan dalam rangkaian pernyataan yang menyatakan hal-hal positif dan mendukung mengenai suatu objek dalam hal ini berhubungan dengan kesediaan untuk melakukan pemeriksaan lanjutan setelah USG payudara. Teori Lawrence Green (1980) menyatakan bahwa dukungan petugas kesehatan menjadi salah satu faktor pendorong penting yang mempengaruhi tindakan seseorang dalam memeriksakan diri ke pelayanan kesehatan atau memilih sarana pelayanan kesehatan. $^{13}$ Penelitian yang dilakukan oleh Nurtini (2012) menyatakan sikap positif dari petugas kesehatan memiliki cakupan IVA yang tinggi yaitu 37,1 persen sedangkan sikap negatif dari petugas kesehatan memiliki cakupan IVA sebesar 11,2 persen. Begitupula dengan perilaku petugas kesehatan yang aktif memiliki cakupan IVA tinggi yaitu 38,2 persen dan perilaku pasif yaitu 10,1 persen. $^{22}$ Penelitian Yuliwati (2012) mendapatkan proporsi WUS yang berperilaku IVA baik sebanyak 72,9 persen mendapat dukungan petugas baik dan sebanyak 32,3 persen mendapat dukungan petugas kurang baik. $^{20}$

Dukungan keluarga merupakan salah satu faktor yang mempengaruhi seseorang melakukan upaya deteksi dini maupun pemeriksaan lanjutan kanker payudara. Penelitian ini menunjukkan bahwa terdapat pengaruh antara dukungan keluarga dengan pemeriksaan lanjutan setelah USG payudara. Penelitian Yuliwati (2012) memperoleh nilai OR 5,587. Hasil ini menunjukkan bahwa dukungan suami atau keluarga, berpeluang 5,587 kali lebih besar untuk berperilaku IVA yang baik. ${ }^{20}$ Penelitian Dyanti \& Suariyani (2016) menyatakan bahwa penderita kanker payudara yang mendapat dukungan kurang dari suami/keluarga berisiko 4,35 kali untuk mengalami keterlambatan dalam melakukan pemeriksaan awal ke pelayanan kesehatan. ${ }^{15}$ Demikian juga penelitian Septiani dan Suara (2013) tentang hubungan antara dukungan orang tua dengan perilaku SADARI pada siswa SMAN 62 Jakarta pada tahun 2012. Hasil menunjukkan, adanya hubungan yang signifikan dengan nilai OR 4,5 kali lebih besar, antara siswa yang mendapat dukungan orang tua dibandingkan yang tidak mendapatkan dukungan orang tua dengan perilaku SADARI. ${ }^{25}$ Selain itu penelitian lainnya menyebutkan bahwa dukungan keluarga berkontribusi pada perilaku kesehatan seseorang baik berupa dukungan informasional, dukungan instrumental, dukungan penilaian maupun dukungan emosional. ${ }^{26}$

Kelemahan penelitian ini menggunakan desain potong lintang yaitu hanya memotret sesaat, sehingga tidak dapat melihat sebab akibat. Demikian juga sampel dalam penelitian ini dipilih tidak berdasarkan status paparan atau suatu penyakit/kondisi kesehatan lainnya, melainkan dipilih yang diasumsikan sesuai dengan studi yang akan diteliti dan mewakili populasi. Selain itu, penelitian ini hanya dilakukan secara secara deskriptif untuk membahas determinan yang mempengaruhi pemeriksaan lanjutan setelah USG Payudara. Dukungan kabupaten Badung dalam program deteksi dini payudara dengan melaksanakan program jemput bola ke masing-masing banjar, promosi kesehatan oleh petugas serta dukungan pemeriksaan lanjutan bagi masyarakat yang berisiko.

\section{KESIMPULAN}

Determinan yang mempengaruhi wanita dalam melakukan pemeriksaan lanjutan setelah USG Payudara antara lain pengetahuan, biaya, dukungan keluarga, dan dukungan petugas kesehatan. Pada faktor pendidikan, keterjangkauan jarak dan keterpaparan informasi mengenai pemeriksaan lanjutan tidak terdapat hubungan secara statistik.

\section{SARAN}

Pemberian sosialisasi tentang kanker payudara yang dilaksanakan oleh setiap UPT di Kabupaten Badung tentang deteksi dini kanker payudara sendiri (SADARI) dan faktor risiko kanker payudara kepada wanita. Selain sosialiasi tentang kanker payudara kepada wanita, perlu juga dilakukan sosialisasi kepada keluarga/suami mengenai perlunya dukungan dari pihak keluarga/suami kepada wanita/istri yang dicurigai memiliki kelainan pada payudara untuk tetap melakukan pemeriksaan 
lanjutan kanker payudara. Sehingga diharapkan peran keluarga dalam memberikan dukungan moril, finansial, dan fasilitas untuk wanita/istri dalam melakukan pemeriksaan lanjutan. Agar program pemeriksaan lanjutan ini berjalan, diharapkan pemerintah melaksanakan peningkatan sosialiasasi kepada masyarakat mengenai program Jaminan Kesehatan Nasional (JKN) yang dilaksanakan oleh Badan Penyelenggara Jaminan Sosial (BPJS) Kesehatan tentang manfaat jaminan pemeriksaan deteksi dini kanker payudara bagi para wanita, khususnya yang sudah terdaftar menjadi peserta serta meningkatkan cakupan penggunaan asuransi kesehatan kepada masyarakat yang belum memiliki jaminan kesehatan tersebut.

\section{UCAPAN TERIMA KASIH}

Peneliti mengucapkan terima kasih kepada Dinas Kesehatan Kabupaten Badung yang telah memberikan ijin untuk pengambilan data awal, selain itu ucapan terima kasih kepada responden yang telah bersedia untuk menjadi responden dalam penelitian ini.

\section{DAFTAR PUSTAKA}

1. Departemen Kesehatan RI. Buku Saku Pencegahan Kanker Leher Rahim \& Kanker Payudara. 2009.

2. World Health Organization. Global Status Report on Noncommunicable Diseases. World Health Organization. 2010;53(9):1689-99.

3. Kemenkes RI. Pusat Data dan Informasi Kementerian Kesehatan RI. 2015.

4. Estimated Cancer Incidence, Mortality and Prevalence Worldwide in 2012. Global Burden Cancer. 2012.

5. Susanti N, Mintarsih S. Gambaran Tingkat Pengetahuan Mahasiswa Semester 2 tentang SADARI (Pemeriksaan Payudara Sendiri) di Prodi DIII Keperawatan STIKES PKU Muhammadiyah Surakarta. PROFESI. 2014;10(September 2013):1-5.

6. Situasi Penyakit Kanker [Internet]. Kementerian Kesehatan. 2015 [cited 2016 May 17]. Available from: http://www.depkes.go.id/article/view/1502 1800011/situasi-penyakit-kanker.html

7. Mediasta, E.H. Risiko Penggunaan Kontrasepsi Hormonal terhadap Kejadian Kanker Payudara di RSUP Sanglah Kota Denpasar Tahun 2011. Universitas Udayana; 2012.

8. Taha, M.N.A.B. Prevalensi dan Karakteristik Penderita Kanker Payudara di Departemen Bedah Rumah Sakit Umum Pusat Haji Adam Malik Medan Tahun 2010. Universitas Sumatera Utara; 2010.

9. Wahyuni D, Harahap WA. Hubungan Tingkat Pengetahuan dan Sikap terhadap Pelaksanaan SADARI pada Ibu Rumah Tangga di Kelurahan Jati. Jurnal Kesehatan Andalas. 2015;4(1):89-93.

10. Mulyani,dkk. Kanker Payudara dan PMS pada Kehamilan. Yogyakarta: Nuha Medika; 2013.

11. Desanti OI, Sunarsih IM. Persepsi Wanita Berisiko Kanker Payudara tentang Pemeriksaan Payudara Sendiri di Kota Semarang Jawa Tengah. Berita Kedokteran Masyarakat. 2010;26(3):152-61.

12. Huang Y, Kang M, Li H, Li JY, Zhang JY, Liu LH, et al. Combined Performance of Physical Examination, Mammography, and Ultrasonography for Breast Cancer Screening among Chinese Women: a Follow-up Study. Current Oncology.2012;19:22-30.

13. Notoatmodjo S. Ilmu Perilaku Kesehatan. Jakarta: PT Rineka Cipta; 2014.

14. Breast Cancer Early Detection and Diagnosis [Internet]. American Cancer Society. 2018 [cited 2020 Jun 3]. Available from: https://www.cancer.org/healthy/findcancer-early/cancer-screeningguidelines/american-cancer-societyguidelines-for-the-early-detection-ofcancer.html

15. Dyanti GAR, Suariyani NLP. FaktorFaktor Keterlambatan Penderita Kanker Payudara Dalam Melakukan Pemeriksaan Awal Ke Pelayanan Kesehatan. Jurnal Kesehatan Masyarakat. 2016;11(2):276.

16. Pradono J, Sulistyowati DN. Hubungan antara Tingkat Pendidikan, Pengetahuan tentang Kesehatan Lingkungan, Perilaku Hidup Sehat dengan Status Kesehatan. Studi Korelasi pada Penduduk Umur 10-24 tahun di Jakarta Pusat. Buletin Penelitian 
Sistem Kesehatan. 2013;17(1):89-95.

17. Mirayashi D, Raharjo W, Wicaksono A. Hubungan antara Tingkat Pengetahuan Tentang Kanker Serviks dan Keikutsertaan Melakukan Pemeriksaan Inspeksi Visual Asetat di Puskesmas Alianyang Pontianak. Jurnal Mahasiswa PSPD FK Univ Tanjungpura. 2014;1(1):1-18.

18. Savitri,dkk. Kupas Tuntas Kanker Payudara Leher Rahim \& Rahim. Yogyakarta: Pustaka Baru Press;

19. Hastuti RY. Hubungan Tingkat Pengetahuan Tentang Kanker Payudara dengan Perilaku Deteksi Dini Kanker Payudara pada WUS di Desa Mojodoyong Kedawung Sragen. Universitas Sebelas Maret; 2010.

20. Yuliwati. Faktor-faktor yang Berhubungan dengan Perilaku WUS dalam Deteksi Dini Kanker Leher Rahim Metode IVA di Wilayah Puskesmas Prembun Kabupaten Kebumen Tahun 2012. Universitas Indonesia; 2012.

21. Rahma Erlina, TA Larasati, Betta Kurniawan. Faktor-Faktor Yang Mempengaruhi Ibu Hamil Terhadap Kunjungan Pemeriksaan Kehamilan di Puskesmas Rawat Inap Panjang Bandar Lampung. Medical Journal of Lampung
University. 2013;2(4):29-34.

22. Nurtini, N.M. Hubungan antara Faktor Presdiposisi, Pendukung dan Pendorong dengan Cakupan Inspeksi Visual Asam Asetat di Kota Denpasar. Universitas Udayana; 2012.

23. Martini, N.K. Hubungan Karakteristik, Pengetahuan dan Sikap Wanita Pasangan Usia Subur dengan Tindakan Pemeriksaan Pap Smear di Puskesmas Sukawati II. Universitas Udayana; 2013.

24. Rohmawati I. Faktor-faktor yang Berhubungan dengan Perilaku Wanita Usia Subur dalam Deteksi Dini Kanker Serviks dengan Metode IVA (Inspeksi Visual dengan Asam Asetat) di Wilayah Kerja Puskesmas Ngawen 1 Kabupaten Gunung Kidul Tahun 2011. Universitas Udayana; 2011.

25. Septiani S, Suara M. Faktor-faktor yang Berhubungan dengan Perilaku Pemeriksaan Payudara Sendiri (SADARI) pada Siswa SMAN 62 Jakarta 2012. Jurnal Kesehat Ilmiah. 2013;5(1):31-5.

26. Oktalina O, Muniroh L, Adiningsih S. Hubungan Dukungan Suami Dan Dukungan Keluarga Dengan Pemberian Asi Eksklusif Pada Ibu. Media Gizi Indonesia. 2016;10(1):64-70. 